\title{
原著
}

\section{不正咬合のふるいわけを前提とした各種指数の 比較に関する研究}

\author{
品田佳世子佐々木 好幸米満正美 \\ 岡 田 昭五郎
}

東京医科歯科大学歯学部予防歯科学教室（指導：岡田昭五郎教授）

（1990年6月29日 受付）

\section{A Comparative Study with Five Indices of Malocclusion for Evaluating Treatment Needs}

\author{
Kayoko Shinada, Yoshiyuki Sasaki, Masami Yonemitu \\ and Shogorou Okada \\ Department of Preventive Dentistry and Public Health, Faculty of Dentistry, Tokyo Medical and Dental University \\ (Director : Prof. Shogoro Okada)
}

The purpose of this study was to investigate the utility of five indices of malocclusion (NMT, MI, HLDI, OFI and DI) for evaluating the necessity of orthodontic treatment.

One dentist scored malocclusion in 40 females (Age : 18 23). Then, another orthodontist assessed the treatment needs for malocclusion on the same subjects. We compared each score with the assessment by the orthodontist and determined the screening level score of the treatment needs for malocclusion.

The sensitivity and specificity were calculated for 5 indices respectively. The selection using MI (screening level score : 12) resembled mostly the assessment by the orthodontist, followed by NMT (screening level score : 8) and DI (screening level score: 8 ). But the time required to score using MI was longer than using DI, and the reproducibility of NMT was inferior to DI.

The subjects in this study had a high frequency of crowding $(22.5 \%)$, and DI was highly correlated to the arch length discrepancy $(r=-0.898)$.

From these results, it was suggested that DI was a suitable index for evaluating the treatment needs for malocclusion, particularly crowding.

\section{I 。緒言}

わが国では，近年，若年者の間で叢生の頻度が 増大しつつあることが指摘されている1,2)。神奈 川県で曾科医師を対象とした調查では, 近年, 母 親からの歯列不正に関する相談が多くなってき ていると報告されている3)。一方，不正咬合に
関する疫学的研究は, 龋蝕や歯周疾患に比べると 少ない4,5)。過去には社会的ニーズが少なかった 不正咬合も近年は国民の関心が強くなってきてお りとくに叢生の者が目立って増加していること から，一般臨床歯科医も容易に使光て再現性の高 い不正咬合の評価法を検討する必要があると思わ れる。 
不正咬合を数早的に咷価する方法としては, Massler と Frankel ${ }^{6)}$ の平均鮫合異常料数 Average Number of Maloccluded Teeth (NMT), Vankirk と Pennell ${ }^{7}$ ) の歯列異常指数 Malalignment Index (MI), Draker ${ }^{8)}$ の Index of $\mathrm{Ha}$ ndicapping Labio-lingal Deviations (HLD Index, 以下 HLDI), Poulton と Aaronson ${ }^{9)}$ の Occlusion Feature Index (OFI), Grainger ${ }^{10}$ ) Treatment Priority Index (TPI), 渡辺 ${ }^{11)}$ と米满 ら12)の Discrepancy Index (DI) などがあり, こ れらの指数について臨床的診断との比較を行った 報告も又られる13,14)。

本研究は近年の佂正咬合とりか教生の增加に 伴って，一般臨床に携わっている料科医師が健球 郃相で矯正治療を要する程度の不正咬合か否かを ふるいわける際に，どの指数が再現性，僧使性お よび効率の点で適しているかを㛟封したものであ る。

\section{II. 対象および方法}

\section{1. 対 象}

本学蔽学部付属蔽科衛生士学校学生60名のうち 矯正治療の絴験がなく, Hellmanの菊㴹命 NAに 達し，智画を除く永久粕 28 本を有する者 40 名 （18２3筬，平均19.05 土0.96藏）を被娭者とし to

\section{2. 研究方法}

1) 顎模型の作成

対象者40名について，アルジネ一ト印象材を用 いて対象者の上下顎糊列の印象を採取し，ただち に硬石行を注入して各人の平行模型を作成した。 また，加熱軟化したバイトワックスを用い各人の 山腔内で中心咬合位をとらせながら硬化させて, 慔型上での咬合位を再現させた。

\section{2 ）口腔内骖查}

任意に抽出した20名の対象者について，NMT， MI, HLDI, OFI, DI の 5 種の不正咬合に関する Index の評価を次に示寸診査基準に従って診査 し 6 12,15), 被梚者冬人について 5 種のIndex それ ぞれの Scoreで纺した。
NMT : 個々の米が米列中の正常位から近遠心 的・煩舌的転位, 高位, 低位, 括上び回転のいず れかのある采を咬合異常爽として数え，全顎にお ける異常米数で表す。

MI：指定されたプラスチック定規を使用し， 理想的配列（ideal arch line）から45度未満の念 転もしくは $1.5 \mathrm{~mm}$ 未満の煩舌側転位のある萪に 1 点, それ以上の捻転および頓舌側転位のある場 合には 2 点を与え, その合計点数で表す。

HLDI：（1）口蓋裂（あり；+15点），（2） 外傡などで上顎前蔽の喪失（あり; +15点),

(3) Overjet (上顎切粦切縁から下顎切歯唇面 の距離mmを点数), (4) Overbite (過蓋の最大 部位を対合糞上にマークし，そこから歯の切縁ま での距敞倠mmを点数)，（5）下顎前突（前齿部で 嵌も突出した下顎切粰の唇面から上顎切歯の唇面 までの距離 $\mathrm{mm} \times 5$ を点数)，（6）開咬 (開咬最 大部位における上顎歯切縁から下顎歯切縁までの 距離 $\mathrm{mm} \times 4$ を点数)，（7）転位 (正常峛列弓か ら最大唇舌転位霜までの距離 $\mathrm{mm}$ を点数）の7項 |1の5ち（1），（2）は有無を，（3）（7）は ノギスを用いて 4 括 5 入法により $\mathrm{mm}$ 単位で測定 し, 項目により指定の倍率を乗じ合計した数值で 优す。

OFI : (1) 下顎前歯の叢生状態（正常は 0 点, 合計して右下顎中切米幅径の $1 / 2$ 程度の重なり は1点, 歯冠幅径に相当する程度の重なりは2 点，てれ以上の重なりは 3 点), （2）右側臼歯部 を偭面より観祭した咬合状態（正常は 0 点, 咬頭 と咬頭が咬み合っている状態は 2 点, その中間状 態は 1 点),（3）前歯部の垂直的被蓋状態（下顎 中切朄冠長の $1 / 3$ 以下の被蓋は 0 点, 歯冠長の $1 / 3 \sim 2 / 3$ までの被蓋は 1 点, 雨冠長の $2 / 3$ 以上の過蓋は 2 点), （4）前雨部の水平的突出状 態 (上顎切歯唇面から下顎切霜唇面までの距離が $0 \sim 1.5 \mathrm{~mm}$ は 0 点, $1.5 \sim 3 \mathrm{~mm}$ までの突出は 1 点, $3 \mathrm{~mm}$ 以上の突出は 2 点）の合計点数で表 于。

DI : 隣接する夹の配列状態より, 空隙 ( 0 点), 正常接触 (1 点), 唇煩舌的ずれ ( 2 点; 前雪部 
では妇縁の厚々以上，日画部では煩側または舌側 の咬頭の煩舌側幅以上のずれ），2歯が重なっ ている（3点; 両歯牙が咬合平面まで達しており 煩唇舌的に重なっている場合，または一方の歯小 が咬合平面まで達して招らず咬合面側から又て重 なっている場合）のそれぞれの点数を与える。上 下顎歯間部合計26筒所の点数の総和から26を差し 引いた数值で表す。

診査はすべての Index について知正治療の経 験のない歯科医師が行い，それぞれの診査に要す る時間を被唡者ごとにストップウオッチで測定し た。

3）石膏模型を用いた䛦相

40 組の石高模型それぞれについて口腔内䛦查と 同じ基準によって 5 種の Index それぞれの score を算出した。この際，口腔内骖相を行った20名の 模型上の診査については誩査に要する時間を測定 した。なお，模型上の診査はすべて口腔内䛦查を 行った同一の歯科医師が行った。

また，この娭査者の変動をみるため，6力月後 に口腔内骖查を行った同じ対象者20組の模型を用 いて, 同様の評価を行った。

Available arch length $\varepsilon$ Required arch length は真鍮線と $1 / 2 \mathrm{~mm}$ の副尺目盛りのついた ノギスを用いて测定し、それぞれの值から Arch length discrepancy を算出した16)。

Available arch length: 左側第 1 大目歯近心

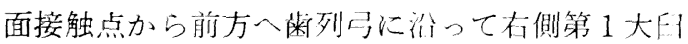
歯近心面接触点にいたる長さ

Required arch length : 左側第 2 小四料から有 側第 2 小臼歯までの歯冠幅径の総和

Arch length discrepancy : Available arch length から Required arch length を引たた值

以上の診査を行った歯科医師とは別人で 6 年の 臨床経験を有する矯正歯科専門医が，同じ40組の 顎模型について矯正治療を要するか否かを判定し た。判定の結果は個々の石高模型から矯正治療を 要すると判断される者 (要矯正者), 矯正治療は 必要としないと判断される者（矯正不要者），ど ちらとも判断できない省の 3 群に分類した。

\section{4) Screening level score}

ある疾病の Screening test の有用性を判断す る指標として, 敏感度（ST：疾病ありのらち㛟 査で陽性となる制合)，と特異度（SP：疾病なし のらち娭查で陰性となる割合）が目安になる17)。 あらかじめ設定した Screening level score でふ るいわけた結果の敏感度および特異度がそれぞ れ 1（的中率 $100 \%$ ）に近い注どその娭查法が Screening test として適当な方法と考光られ，予 防や医療の領域で広く使われている。

本研究では, 矯正㐘科専門医が矯正治療の必要 性を判断した結果を臨床的な結果とし，矯正歯 科専門でない粦科医師が診査して求めた各 Index の数值を Screening test の結果として敏感度と 特異度を算出した。 Screening level scoreは，そ れぞれのIndex の平均俻を求め，ての平均值削 後の整数值を仮の Screening level score として, まず敏感度と特異度を算出した。元の結果から敏 感度と特異度の合計が最も高い值になるときの Score の整数值を選び, その Index の Screening level score とした。

\section{III. 結果}

\section{1. 診査の所要時間}

任意に抽出された 20 名に対して行った口腔内診 查之模型上の診査の所要時間の平均值を表 1 に示 す。各Index の診査に要する時間の長短は口腔 内䧐查と模型上診査で同樣な傾向を示し，OFIが 最も短く,ついでNMT, DIの順であった。所要 時間の平均值の差の有意性を $\mathrm{t}$ 娭定によって唡討

表 1 各 Index の診查所要時間

\begin{tabular}{l|c|c}
\hline \multirow{2}{*}{ Index } & 所 要 時 間 $($ 秒 $)$ \\
\cline { 2 - 3 } & 口腔内診査 & 不简枋型上の診査 \\
\hline NMT & $33.6 \pm 12.2$ & $31.5 \pm 10.0$ \\
MI & $48.1 \pm 21.6$ & $46.7 \pm 20.7$ \\
HLDI & $49.1 \pm 12.5$ & $40.7 \pm 7.7$ \\
OFI & $25.8 \pm 9.8$ & $25.9 \pm 7.1$ \\
DI & $34.8 \pm 15.9$ & $31.7 \pm 7.4$ \\
\hline
\end{tabular}

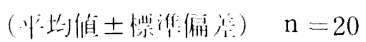


した結果, OFIは他の４種のIndex の場合より 診査に要する時間が危険率 $5 \%$ で有意に短かっ た。NMTとDI との間には口腔内の診㭗でも模 型上の診查でも危険率 $5 \%$ で有意な差異は認めら れなかった。MI と HLDI の診查には他の 3 種の Index の場合より危険率 $5 \%$ で有意に長時間を要 寸る結果が得られ，口腔内診查でも模型上の診査 でもMI と HLDI の間には危険率 $5 \%$ で有意な 差異は認められなかった。

\section{2. 口腔内診査と模型上の診査との相関}

口腔内診査のScore と模型上での Score の平均 值ならびに両者の相関関係を相関係数として表 2 に示す。相関係数はいずれのIndexも $0.1 \%$ 危険 率で有意な相関が得られたが，相関係数は HLDI が 0.923 と最も高く, DI が 0.894 とついで高い值 を示した。最低值は OFI の0.709であった。

\section{3. 石高模型上における 2 回の診查の変動}

口腔内猃查を行った同じ対象者20組の石高模型 について同一骖査者が同一模型上で 6 力月の間隔 をあけて診査した各Indexの平均值と第 1 回，第 2 回の診查結果の相関係数を住 3 に示す。 5 種の

表 2 山腔内診芯と模型上での診査の斗均值なら びに両者の相関

\begin{tabular}{|c|c|c|c|}
\hline \multirow{2}{*}{ Index } & \multicolumn{2}{|c|}{ Score の斗均值 } & \multirow{2}{*}{$\begin{array}{l}\text { 両者 の } \\
\text { 相関倸数 }(r)\end{array}$} \\
\hline & 口腔内診植 & 模型上の診查 & \\
\hline NMT & 4. $72 \pm 3.21$ & $5.25 \pm 4.12$ & 0.807 \\
\hline MI & $5.45 \pm 3.49$ & $6.15 \pm 4.86$ & 0.819 \\
\hline HLDI & $7.04 \pm 3.56$ & $6.28 \pm 3.39$ & 0.923 \\
\hline OFI & $2.80 \pm 2.11$ & $3.05 \pm 1.88$ & 0.709 \\
\hline DI & $3.30 \pm 4.09$ & $2.65 \pm 5.22$ & 0.894 \\
\hline
\end{tabular}

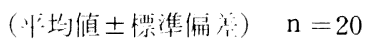

Index はすべて危険率 $0.1 \%$ で有意な相関係数が 得られた。各Indexの間では, HLDI の相関係数 が 0.960 と最も高く, ついでDI が0.959 と高い值 を示し，NMTが最も低い值を示した。Z変換に よって相関係数の差の検定を行った結果では, NMT とDI の間, NMT と HLDI の間に危険率 $5 \%$ で有意な差が認められた。

\section{Arch length discrepancy と5 種の Index との} 相関

40組の石膏模型について Arch length discrepancy の上下顎合計值は表 4 のような分布を示し た。その平均值は $-4.83 \mathrm{~mm}$ で本研究の 対象は 全体として歯冠幅径に比べて顎が小さい discrepancyの傾向にある。上下顎合計の Arch length discrepancy の值と 5 種の Index の数值との間に は表 5 に示すように，いずれも危険率 $0.1 \%$ で有 意な負の相関が得られた。DI が最も高い負の相 関係数を示し, DI と NMT, DI と HLDI, DI と OFI との間には，いずれの場合においても危険率 $1 \%$ で有意な差異が認められた。

表 3 同一診査者の診相結果の変動（模型上, 6 力月間隔)

\begin{tabular}{|c|c|c|c|}
\hline \multirow{2}{*}{ Index } & \multicolumn{2}{|c|}{ Score の平均值 } & \multirow{2}{*}{$\begin{array}{c}\text { 相関係数 } \\
\text { r }\end{array}$} \\
\hline & 1 回目 & 2 回目 & \\
\hline NMT & $5.25 \pm 4.12$ & $5.55 \pm 4.05$ & $0.830^{-}$ \\
\hline MI & $6.15 \pm 4.86$ & $6.30 \pm 4.49$ & $0.865 *$ \\
\hline HLDI & $6.28 \pm 3.39$ & $7.00 \pm 3.95$ & $0.960^{-}$ \\
\hline OFI & $3.05 \pm 1.88$ & $2.65 \pm 1.46$ & 0.870 \\
\hline DI & $2.65 \pm 5.22$ & $2.85 \pm 4.90$ & 0.959 \\
\hline
\end{tabular}

(妆均值士標準偏疾) $*: \mathrm{p} \leqq 0.05, \mathrm{n}=20$

表 4 Arch length discrepancy の分布（上下顎合計值）

\begin{tabular}{c|cccccc}
\hline \hline $\begin{array}{c}\text { Arch length } \\
\text { discrepancy } \\
(\mathrm{mm})\end{array}$ & -20 未満 & -10 未満 & -5 末満 & 0 未満 & 5 未満 & \\
\hline 対 象 者 数 & 3 & 5 & 7 & 11 & 11 & 3 \\
\hline
\end{tabular}

$\mathrm{n}=40$ 
表 5 Arch length discrepancy（上下枵合計值）と各 Index Score との相関

\begin{tabular}{|c|c|c|c|c|c|}
\hline \multirow{2}{*}{$\begin{array}{l}\text { Arch length } \\
\text { discrepancy } \\
\text { 平均值士標準偏差 } \\
\qquad(\mathrm{mm})\end{array}$} & \multicolumn{5}{|c|}{ 相 関 係 数（r) } \\
\hline & NMT & MI & HLDI & OFI & DI \\
\hline$-4.83 \pm 9.21$ & -0.650 & -0.826 & -0.610 & -0.665 & -0.898 \\
\hline
\end{tabular}

表 6 各 Index に㧍ける矮正治療の必要性の Screening level score と それぞれの敏感度ならびに特異度

\begin{tabular}{|c|c|c|c|c|c|c|}
\hline \multirow[t]{2}{*}{ Index } & \multicolumn{3}{|c|}{$\begin{array}{l}\text { 専門医による矯正治療の必要性 } \\
\text { 別 Score の平均值とその人数 }\end{array}$} & \multicolumn{2}{|c|}{$\begin{array}{l}\text { Screening level score } \\
\text { を基に治療の必要性を } \\
\text { ふるいわけた人数 }\end{array}$} & \multirow{2}{*}{$\begin{array}{l}\text { Screening } \\
\text { level } \\
\text { score } \\
\text { ST, SP }\end{array}$} \\
\hline & $\begin{array}{l}\text { 治療の } \\
\text { 必要性 }\end{array}$ & Score & 人数 & + & - & \\
\hline \multirow{4}{*}{ NMT } & + & $9.57 \pm 3.52$ & 14 & 11 & 3 & S. $1 . s .=8$ \\
\hline & \pm & $8.56 \pm 4.33$ & 9 & 5 & 4 & $\mathrm{ST}=0.786$ \\
\hline & - & $4.82 \pm 2.65$ & 17 & 2 & 15 & $\mathrm{SP}=0.882$ \\
\hline & total & $7.33 \pm 3.97$ & 40 & 18 & 22 & \\
\hline \multirow{4}{*}{ MI } & + & $17.43 \pm 7.12$ & 14 & 11 & 3 & S. $1 . \mathrm{s} .=12$ \\
\hline & \pm & $11.33 \pm 5.83$ & 9 & 4 & 5 & $\mathrm{ST}=0.786$ \\
\hline & - & $6.41 \pm 3.89$ & 17 & 1 & 16 & $\mathrm{SP}=0.941$ \\
\hline & total & $11.38 \pm 7.35$ & 40 & 16 & 24 & \\
\hline \multirow{4}{*}{ HLDI } & + & $13.52 \pm 6.69$ & 14 & 9 & 5 & S. 1.s. $=9$ \\
\hline & \pm & $7.79 \pm 3.93$ & 9 & 3 & 6 & $\mathrm{ST}=0.643$ \\
\hline & - & $5.71 \pm 2.37$ & 17 & 1 & 16 & $\mathrm{SP}=0.941$ \\
\hline & total & $8.90 \pm 5.72$ & 40 & 13 & 27 & \\
\hline \multirow{4}{*}{ OFI } & + & $4.71 \pm 2.05$ & 14 & 11 & 3 & S. $1 . \mathrm{s} .=4$ \\
\hline & \pm & $3.00 \pm 1.41$ & 9 & 4 & 5 & $\mathrm{ST}=0.786$ \\
\hline & - & $2.59 \pm 1.42$ & 17 & 6 & 11 & $\mathrm{SP}=0.647$ \\
\hline & total & $3.43 \pm 1.89$ & 40 & 21 & 19 & \\
\hline \multirow{4}{*}{ DI } & + & $12.63 \pm 7.33$ & 14 & 10 & 4 & S. $1 . s .=8$ \\
\hline & \pm & $5.81 \pm 6.33$ & 9 & 4 & 5 & $\mathrm{ST}=0.714$ \\
\hline & - & $2.62 \pm 3.71$ & 17 & 1 & 16 & $\mathrm{SP}=0.941$ \\
\hline & total & $6.83 \pm 7.20$ & 40 & 15 & 25 & \\
\hline
\end{tabular}

S. 1. s. : Screening level score

$\mathrm{ST}$ : 敏感度, $\mathrm{SP}$ : 特異度

\section{5種の Index の Screening level score と矯正 治療の必要性}

矯正歯科専門医が平行模型によって矯正治療の 必要性を 3 群 (十群 : 要矯正者, 土群 : どちらと
も判断できない者,一群：矯正不要者）に分けた 結果之矯正治療の経験のない歯科医師が 5 種の Index の Score を基にふるいわけを行った結果を 表 6 に示す。矯正専門医による診査の結果では, 


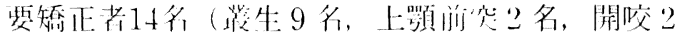

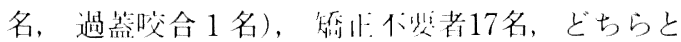
もい党ない者 9 名であった。

NMT については 40 組の石高模型によるScore の平均値は7.33である。そこで, Screening level score を8 に設定した場合，术6に示すように 矯正歯科尃門医が判定した要矯正者 14 名のうち Screening level score 8 以上，すなわちIndexの Scoreを基に要短正と判定さ机た者は11名であ り，敏感度 $(\mathrm{ST})=0.786$ となった。问様に稪正 浰科専門医が矯正を要しないと判定した17名のら ち Screening level score 8 末満, 寸なわり Index のScore 老基に矯正不要と判定された者は15名で あり，特異度 $(\mathrm{SP})=0.882$ となった。 Screening level score を他の整数值に仮に設定した場合に ついても同様に行ってみたが, Screening level score を8に設定した場合が敏感度（ST）と特羁 度（SP）の合計值が最も活い值になった。

MI についても同様にST も高い値になる Screening level score を求めた 結果では12であり，兲6に示すよらにST=0.786. $\mathrm{SP}=0.941$ となった。

HLDI については, Screening level score を 9 に設定した場合，尘 6 に示すよらにST $=0.643$ と低くなるが，SPは0.941 と高くなる。しかし， Screening level score を8に没定すると ST= 0.714と高くなるがSPは0.802 と低くなって，ST とSPの合計值は Screening level score を9
設定した場合に及ばない。

OFI については, Screening level score を 4 に設定した場合， ST $=0.786 ， \mathrm{SP}=0.647$ となり， これ以上 ST と SP の合計值を高くするよらな Screening level score を設定することはできな かった。

DI については, Screening level score を8に 設定した場合， $\mathrm{ST}=0.714 ， \mathrm{SP}=0.941$ となり， $\mathrm{ST}$ とP の合計值は最も高くなった。

\section{DI と歯冠幅径および Available arch length と の関係}

豉生の程度を表す指数として考案された DI に ついて Available arch length および歯冠幅径と の関速性を㛟討するために表 6 に示す DI の Screening level score 8 以上の15名之 7 以下の 25 名 について，上下顎石旁模型上から Available arch length と各粨の窲冠幅径の平均を比較し, 表 7 に亦す。上下顎ともに Available arch length は DI が 8 以上の群はDI が 7 以下の群に比べ，上顎 では危険率 $1 \%$ ，下顎では危険率 $5 \%$ で有意に低 い俏を示した。一方, 個々の歯の歯冠幅径は, DI の 8 以上の群がDI の 7 以下の群に比べ大きい 仳向があり，下顎側切歯㧍よび下顎第 1 小臼歯に おいて，5\%以下の危険率で有意に大きいことが 恋めら的た。

\section{IV. 考察}

Discrepancy は micro-evolusion（小進化）に

表 7 DI score 别 Available arch lengthの平均值ならびに溂冠幅径の平均值

\begin{tabular}{|c|c|c|c|c|c|c|c|c|}
\hline & \multirow{2}{*}{$\begin{array}{c}\text { DI } \\
\text { score }\end{array}$} & \multirow{2}{*}{$\mathrm{n}$} & \multirow{2}{*}{$\begin{array}{l}\text { Available } \\
\text { arch } \\
\text { length }(\mathrm{mm})\end{array}$} & \multicolumn{2}{|r|}{ 临 } & \multicolumn{2}{|c|}{ 冠 幅 径 (mm) } & $\mathrm{n}=80$ \\
\hline & & & & 第 2 小臼蔽 & 第 1 小臼米 & 犬 & 側 切 峲 & 中 切歯 \\
\hline \multirow{3}{*}{ 上 唨 } & 8 & 15 & $71.53 \pm 3.82$ & $7.25 \pm 0.43$ & $7.43 \pm 0.47$ & $8.17 \pm 0.51$ & $7.35 \pm 0.50$ & $8.42 \pm 0.43$ \\
\hline & & & )** & ) n.s. & ) n. s. & ) n. s. & ) n.s. & ) n. s. \\
\hline & $7 \geqq$ & 25 & $75.60 \pm 3.81$ & $7.05 \pm 0.42$ & $7.40 \pm 0.38$ & $7.89 \pm 0.53$ & $7.11 \pm 0.43$ & $8.36 \pm 0.49$ \\
\hline \multirow{3}{*}{ 下 頑 } & $8 \leq$ & 15 & $61.75 \pm 4.99$ & $7.47 \pm 0.35$ & $7.59 \pm 0.39$ & $6.90 \pm 0.41$ & $6.33 \pm 0.33$ & $5.75 \pm 0.30$ \\
\hline & & & )$*$ & ) n.s. & )* & ) n.s. & )** & ) n.s. \\
\hline & $7 \geqq$ & 25 & $65.33 \pm 3.40$ & $7.21 \pm 0.52$ & $7.29 \pm 0.46$ & $6.72 \pm 0.49$ & $6.00 \pm 0.37$ & $5.53 \pm 0.36$ \\
\hline
\end{tabular}

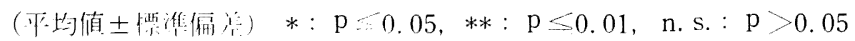


よる過程であり，その要因としては食生態学的な 変化による顎の縮小が考兄られるといら説があ る $^{1,18)}$ 。厚生省の歯科疾患実態調査によると, 矯 正治療の必要性のある者は昭和 44 年度の調査では $13.4 \%$, 昭和 56 年度の調査では $18.0 \%$ と報告され ている ${ }^{19)}$ 。昭和56年度の調査結果执よび須佐美 ら5)の報告によると不正咬合のなかでも坟生の頻 度が高く，20歳未満の不正咬合のある者のうち， 約 $1 / 3$ は叢生があると報告されている。また， 昭和 62 年度の保健福祉動向調查の結果によると, 歯並びが気になる人は此較的若い人に多く，潜在 的な矯正治療希望者の多いことが示唆される20)。

上村ら2（鹿児島市に执いて，不正咬合のなか でも叢生が若い世代で増加の傾向にあり，Available arch length の減少とともに, Required space が増大していると報告している。また，上 村ら ${ }^{21)}$ は, 全国 6 地区の歯の大きさの世代差を検 討した結果，世代が若いほど中切歯から第 2 小曰 歯にかけて歯冠幅径が増大寸る傾向が認められて おり，たんばく質摂取の推移と関連があるのでは ないかと述べている。歯冠幅径については，現代 のラップ人22)，スウェーデン人 ${ }^{23)}$ ，イギリス人 ${ }^{24)}$ でも大きくなっているという報告もある。今回の 研究において, 叢生度の高い群は Available arch length が有意に小さく，個々の歯の歯冠幅径は ほぼ全霜にわたって大きい傾向が認められ，前述 の報告と同椂の傾向が示唆された。前述の霜科疾 患実態調查 ${ }^{19)}$ や保健福祉動向調査 ${ }^{20)}$ の結果を考兄 合わせると，不正咬合のなかでもとくに叢生は頻 度が高く, 日本人の若年者の今後の問題として考 光必要があろら。

集団を対象とした疫学的調查法や歯科集団娭診 において疾病・異常の必要性をふるいわける際に は, 簡便で再現性が高く, かつ, 効率がよい検出 方法が要求される。今回，われわれは不正咬合に ついて 40 人の対象者を一人の検査者が不正咬合の 5 種の Index (NMT, MI, HLDI, OFI, DI) を用 いてふるいわけることを試みた。その結果, 簡便 性について重要な要因となる診査に要する所要時 間は, OFI が最も短く, HLDI や MI は長かっ

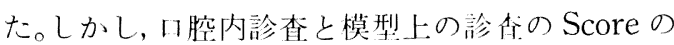
相関係数は, HLDI が最も高く，ついでDI が高 く, OFIは最も低かった。これは，HLDI が実際 の計測值を用いるため, 同一診査者内に打ける変 動が少なく再現性が高くなったためと考兄られ る。けれども HLDI では， ギスを使用するた め，簡便性のらえからは他の４種の Index に比 べると，非常に繁雑であった。OFI は逆に簡便性 のらえからは診相項目が少ないので短時間で終了 するが，主観的に咬合の状態を点数として表すの で境界の場合の判定が難しい。口腔内診査で口唇 が存在する場合は主観が入りやすく, Score に微 妙な差が現れるために模型上での診䍒々の間の相 関が低くなったと考兄られる。

口腔内診相と模型上での診査の相関係数は DI がHLDI についで高く, 所要時間は OFI につい で短く、模型上で 6 力月の間隔を置いて診査した 結果の再現性もHLDIについで高い值を示した。 再現性と簡便性の雨者を勘案して考光るとDI は 不正咬合のふるいわけに用いるには比較的有用な Index と思われる。これは，DI の評価法が単純 であり, かつ, 重症度も数最化されることによる と思われる。

同一模型上で期間をあけて同一娭査者内の変動 を調べた結果では，再現性の高いIndex はHLDI とDIであり， NMTが最も再現性は低かった。 NMT で再現性が低くなった理由としては, 診査 結果が単にあり・なしで，正常とみなす許容範囲 が 6 カ月の期間を置いたことにより変動したもの と考えられる。これらの指数の再現性に関して は, 涉谷ら ${ }^{25}$ により, 同様の傾向にあることが報 告されている。

Available arch length $\prec$ Required arch length から算出した Arch length discrepancy 值 はDI との負の相関性が最も高く，叢生に関して はDIが最も正確に評価していると考光られる。 しかし，DI は元来，開咬・過蓋咬合・上顎前突 ・反対咬合・交叉咬合などを評価するIndexでな いため、これらの不正咬合を含めて不正咬合をふ るいわける場合にはDIのみを用いることは不適 
切と思われる。今回の40名の対象者の場合, 要矯 正14名中裳生以外の不正咬合としては開咬2名, 上顎前突 2 名, 過蓄咬合 1 名であり，下顎前突な どは認められなかったので，このよらな結果が得 られたものと思われる。したがって, 治療を要する よらな上顎前突や下顎前突などの症例には, さら にふるいわけるための基準が必要と考兄られる。

矯正霜科医による不正咬合の重症度の判定は,

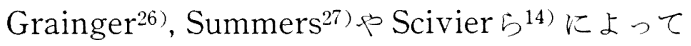
判定者の人数や基準が提案されている。Summers ${ }^{27)}$ によれば, 判定人数は, 矯正治療歯科医 5 名之公衆衛生に携わる歯科医 1 名の計 6 名に上 って，審美性 $(50 \%)$, 機能 $(35 \%)$, 治療の難易 度 $(15 \%)$ で総合判定を行らことを提案してい る。涉谷 ${ }^{13)} は$, Summers の判定法を採用し, 臨 床経験年数 $6 \sim 12$ 年の矯正治療貲科医 3 名の合議 により重症度の順位づけを行い, TPI (Treatment Priority Index）との関係を報告している。

本研究では, 臨床経験 6 年の矯正歯科を専門之 する歯科医師 1 名が，上下顎石亨模型より矯正治 療の必要性を判断し, 要矯正群, 矯正不要群, ど ちらともいえない群の 3 群に分け, 各Index の Screening level score との関係を娭討した。一 般に, ある疾病の Screening test の有効性は, 敏感度（ST）と特異度（SP）がともに高くなる ように設定するのが条件であるが，陽性群と陰性 群との分類が不完全な場合はST と SP ともに高 く設定するのは難しい。今回使用したIndexのな かで，OFI と HLDI はST とSP の両者ともに高 く設定することは困難であることから不正咬合の ふるいわけには適していないのではないかと考光 られる。渡辺, 米満らが提唱しているDI は, 若 い世代に増大しつつある贊生の評価法として考案 されたIndexであるが，近年のわが国の若年者で は叢生が多いこととも関連して，再現性・簡便性 において比較的優れており, 疫学調査のみならず 不正咬合とりわけ叢生の者をふるいわける場合に 利用できる可能性が示唆された。

\section{V. 総括}

本学雪学部付属歯科衛生士学校学生40名を対象 とし，5種の不正咬合に関する Index（NMT， MI, HLDI, OFI, DI) を比較検討した結果，以下 の結果を得た。

1. 同一梚査者が行った, 口腔内診査と模型上 診査結果との相関および同一模型を用いて 6 力月 間隔をあけて診査したときの相関はHLDIが最も 高く，次に DI が高い值を示した。

2. 䛦査所要時間は OFI が最も短く, ついで NMT, DI が短かった。

3. DI と Arch length discrepancy との間に は高い負の相関が認められた。

4. 筒正専門歯科医の判定を臨床的な結果と し, 各Indexについて矯正治療の必要性を判断す る Screening level score を設定し，ふるいわけ を行った。その結果, 敏感度と特異度の合計值で はMI が最も高く,ついでNMT，DI の順であっ た。しかし，MIはDI に比べて診査時間が長く かかること，またNMT は再現性があまりよく ないことを考兄合わせると, 叢生の比較的多い集 団において，DI を用いて矯正の必要性をるるい わけることは有用な方法と考兄られた。

\section{謝辞}

稿を終えるにあたり，本研究にご協力いただきまし た本学第 2 粜科矯正学教室加藤嘉之博士に深く感謝致 します。また、本研究の遂行にあたりご理解とご協力 をいただきました東京医科歯科大学歯学部付属歯科衛 生土学校の教職員ならびに学生の皆様に厚く㧍礼申し あげます。

\section{文 献}

1）井上直彦：歴史時代に打ける咬合の退化. 歯界 展望 $56: 435-444,1980$.

2）上村健太郎, 山内和久, 九良賀野進, 井上直彦, 桑原未代子, 亀谷哲也：鹿児島地区に打ける咬 合と discrepancy の世代差. 日矯歯誌 42 : 409-418, 1983.

3）白勢康夫, 加藤增夫, 橋本 弘, 柏木 勝, 小 笠原正男, 内一宽, 佐々木保博: 神奈川県下 
における永久歯萌出期の歯科保健活動について 第 3 報 フッ化物応用に対する歯科医師会会員 の意識調査について。徫誌 $39: 464-465$, 1989.

4) 米满正美, 品田佳世子, 半田紀穂子, 石井直 美: 東京都区内中学生を対象とした不正咬合の 発現頻度と歯肉炎に関する研究. 口衛誌 35 ： 62-65, 1985.

5）須佐美隆三，滝本和男，岡田平一，北村輝満， 他: 不正咬合の発現に関する疫学的研究. 日矯 歯誌 $30: 230-239,1971$.

6) Massler, M. and Frankel, J. M. : Prevalnece of malocclusion in children aged 14 to 18 years. Am. J. Orthodont. 37 : 751-768, 1951.

7) Vankirk, L. E. and Pennell, E. H. : Assessment of malocclusion in population groups. Am. J. Orthodont. $45: 752-758,1959$.

8) Draker, H. L. : Handicapping labiolingual deviations: A proposed index for public health purposes. Am. J. Orthodont. $46: 295-305,1960$.

9) Poulton, D. R. and Aaronson, S. A. : The relationship between occlusion and periodontal status. Am. J. Orthodont. $47: 690-699,1961$.

10) Popovich, F. and Tompson, G. W. : A longitudinal comparison of the orthodontic treatment priority index and the subjective appraisal of the orthodontist. J. Pub. Health Dent. $31: 2-8,1971$.

11）渡辺和宏：丵生の疫学研究. 口衛誌 $31: 346$, 1981.

12）米満正美, 半田紀穗子, 大原里子, 渡辺和宏: 叢生の評価方法に関する研究. 口衛誌 35 ： $57-61,1985$.

13）淽谷芳郎：T P I の不正咬合評価能についての 研究 II. 口衛誌 $39: 117-123,1989$.

14) Scivier, G. A., Menezes, D. M. and Parker, C. D. : A pilot study to assess the validity Index in English School children. Community Dent. Oral Epidemiol. 2 : 246-252, 1974.

15）島田義弘, 前田 博: 歯科用衛生統計学. 第 2 版, 東京, 1979, 医幽薬出版, 38-44.

16）遠藤 孝, 龟谷哲也, 国武和春, 石川富士郎： 下顎前突の疫学的研究. 日矯蒾誌 $30: 240-$ 246, 1971.

17）柳川 洋, 編：疫学マニュアル，東京， 1985 , 南山堂, 65-69.

18）井上直彦, 角町正勝：Discrepancy とはなにか. 歯界展望 $56: 427-434,1980$.

19）厚生省：昭和56年歯科疾患実態調査報告. 東京, 1983, 口腔保健協会, 134-135.

20）厚生省大臣官房統計情報部：昭和62年保健福祉 動向調査（歯科保健）。東京, 1988, 厚生統計 協会，18-19.

21）上村健太郎, 伊藤学而, 井上直彦：現代日本人 に打计る歯の大きさの世代差. 日矯歯誌 43 : 587, 1984.

22) Kirveskari, P., Hansson, H., Hedegard, B. and Karlsson, U. : Crown size and hypodontia in the parmanent dentition of modern Scolt Lapps. Amer. J. Phys. Anthrop. 48 : 107-112, 1978.

23) Ebeling, C. F., Ingerrall, B., Hedegard, B. and Levin, T. : Secular changes in tooth size in Swedish men. Acta Odont. Scand. 31 : 141-147, 1973.

24) Goose, D. H. : Preliminary study of tooth size in familier. J. Dent. Res. $46:$ 959-962, 1967.

25）渋谷芳郎, 岩倉政城, 島田義弘：不正咬合の疫 学的評価法について。 口衛誌 $34: 24-32,1984$.

26) Grainger, R. M. : Orthodontic treatment priority index.Public Health Service Publication No. 1000 , series 2, No. 25, 1967.

27) Summers, C. J. : The Occlusal Index : Asystem for identifying and scoring occlusal disorders. Am. J. Orthodont. 59 : 552-567, 1971. 